\title{
Catalytic Application of Selenium and Tellurium Compounds as Glutathione Peroxidase Enzyme Mimetics
}

\author{
Eduardo E. Alberto, ${ }^{*, a}$ Vanessa do Nascimento ${ }^{b}$ and Antonio L. Braga ${ }^{*, b}$ \\ ${ }^{a}$ Department of Chemistry, Federal University of Santa Maria, Santa Maria-RS, Brazil \\ ${ }^{b}$ Department of Chemistry, Federal University of Santa Catarina, Florianópolis-SC, Brazil
}

\begin{abstract}
A glutationa peroxidase (GPx) é uma importante enzima que faz parte do sistema de defesa do organismo frente a substâncias nocivas formadas durante o metabolismo do oxigênio, como peróxidos e seus derivados. Diversas estratégias para desenvolver novos miméticos, assim como para aumentar a atividade mimética da GPx em compostos como disselenetos, selenetos e teluretos, vêm sendo propostas nos últimos anos. Nesta revisão é apresentado um balanço, dos últimos dez anos, referente ao desenvolvimento e à avaliação de catalisadores organoselênio ou organotelúrio capazes de mimetizar a atividade da GPx. Diferentes mecanismos de ação destes compostos também são apresentados, de acordo com os novos avanços desta relevante área de pesquisa.
\end{abstract}

This review covers the past decade of intensive research on the design, synthesis and screening of organoselenides and tellurides as catalyst able to mimic the activity of the selenoenzyme glutathione peroxidase (GPx). This important enzyme forms part of the detoxification system in humans which deals with harmful peroxides and their byproducts formed during oxygen metabolism. Several strategies to enhance the GPx-like activity of compounds such as diselenides, selenides and tellurides have been proposed in recent years. Different mechanisms of action of these compounds are also presented in this review highlighting new advances in this exciting research field.

Keywords: glutathione peroxidase (GPx), selenoenzyme, mimetic, selenium, tellurium, selenides

\section{Introduction}

Interest in organochalcogen compounds has been growing since the 1970s, when many reports described the identification of various selenoproteins, which are involved in a widely number of mammals' biochemistry mechanisms. ${ }^{1}$ Synthetic developments and the design of new organoselenium compounds have been attracting considerable attention, particularly due to their ability to mimic natural compounds with important biological properties (e.g., antioxidant, antitumor, anti-inflammatory and anti-infective activity). ${ }^{2}$

Selenoenzymes constitute important mammalian antioxidant enzymes which protect biomembranes and other cellular components from oxidative stress. The oxidative stress is associated to the activity of peroxides and byproducts derived from them, which are produced

\footnotetext{
*e-mail: albraga@qmc.ufsc.br
}

during the metabolism of oxygen in aerobic cells. ${ }^{3}$ These substances are known as reactive oxygen species (ROS) and are harmful substances, which destroy key biological components and cause damage to cell membranes. Several diseases, including neurodegenerative diseases, such as Alzheimer's and Parkinson's disease and other physiological and inflammatory processes are linked to the activity of ROS. ${ }^{4}$

As part of a complex and sophisticated detoxification system, the enzyme glutathione peroxidase (GPx) plays a pivotal role catalyzing the reduction of hazardous peroxides and their byproducts to water or alcohols. ${ }^{5}$ The most important amino acid in the active site of the enzyme is $\mathbf{L}$-selenocysteine $\mathbf{1}$ which is responsible for reducing hydroperoxides at the expense of the tripeptide glutathione GSH $2{ }^{6}$

The ability that the enzyme has to promote the reduction of peroxides lies in the redox properties of the selenol moiety of L-selenocysteine, the catalytic cycle of GPx is 
<smiles>NC(C[Hg])C(=O)O</smiles>

1<smiles>N[C@@H](CCC(=O)NC(CS)C(=O)NCC(=O)O)C(=O)O</smiles>

Figure 1. L-selenocysteine 1 and glutathione 2.

shown in Scheme 1. Initially, the selenol functionality in the enzyme E-SeH 3 reacts with a peroxide molecule to generate the corresponding alcohol or water and selenenic acid $\mathrm{E}-\mathrm{SeOH} 4$. The latter then reacts with one equivalent of glutathione to produce water and the corresponding selenenyl sulfide E-Se-SG 5. The last step is the reaction of glutathione with selenenyl sulfide producing the oxidized glutathione (GSSG) and regenerating the reduced enzyme 3 to resume the catalytic cycle. ${ }^{7}$

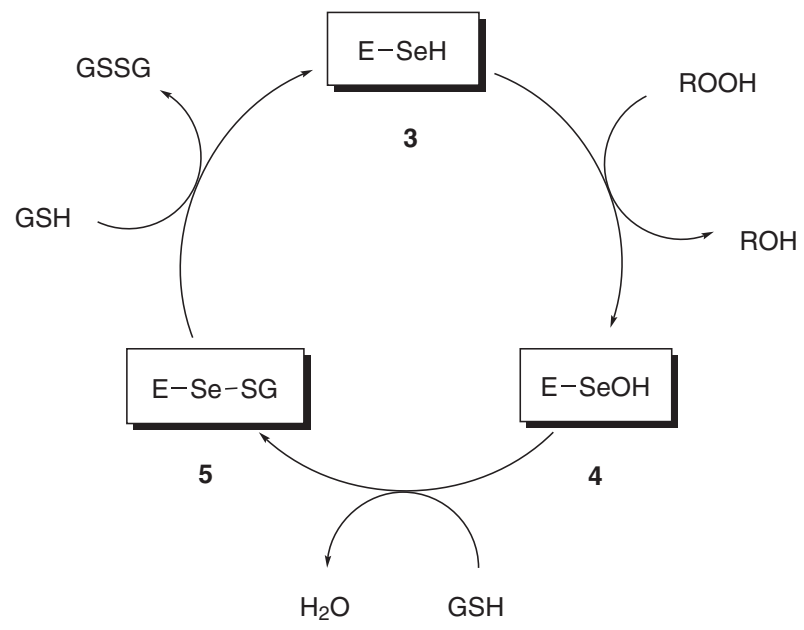

Scheme 1. Redox cycle of GPx.

The total process consists of the reduction of one equivalent of a reactive oxygen species at the expense of two equivalents of glutathione, producing two equivalents of water (when $\mathrm{R}=\mathrm{H}$ ) and oxidized glutathione (GSSG) Scheme 2 .

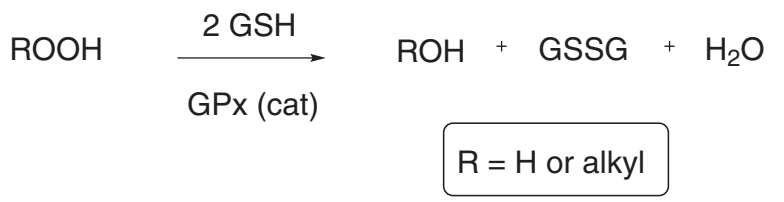

Scheme 2. Global reaction of GPx like.

Since the discovery that selenium plays a pivotal role in GPx enzymes, design and development of new synthetic chalcogen-based catalytic antioxidants have attracted considerable attention. Small molecules of organoselenium and organotellurium compounds have emerged as excellent candidates to act as GPx mimics, due to their well-known ability to undergo two-electron redox cycle between chalcogen (II) and (IV) species. ${ }^{8}$ Although a wide range of structurally diverse organoselenides and tellurides have been investigated by several groups over the past forty years, ${ }^{9}$ the aim of this manuscript is to cover the latest contributions in the field of new organoselenium and organotellurium compounds designed for pronounced glutathione peroxidase like catalytic activity.

\section{Catalytic Application of Chalcogen Compounds as Glutathione Peroxidase Enzyme Mimetics}

\subsection{Organoselenium compounds}

The first synthetic molecule found to be able to mimic the GPx activity was the compound known as ebselen 6, Figure 2. This heterocyclic compound exhibits anti-inflammatory, anti-atherosclerotic and cytoprotective properties with relatively low toxicity. ${ }^{10}$ Because of these properties, ebselen is used as a standard for comparison with selenium compounds in terms of GPx like activity.
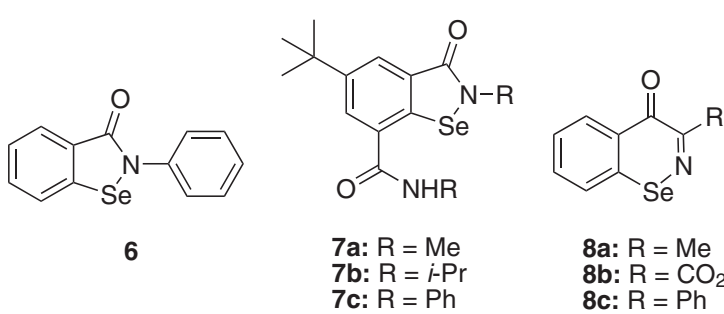

$$
\begin{aligned}
& \text { 8a: } R=M e \\
& \text { 8b: } R=\mathrm{CO}_{2} E t \\
& \text { 8c: } R=P h
\end{aligned}
$$

Figure 2. Ebselen 6 and its derivatives 7a-c and 8a-c.

However, the exact mechanism of its activity has not been elucidated, and this topic is subject of continuous research. Furthermore, its poor solubility in water remains a problem for optimal therapeutic development. In order to enhance its solubility and to increase its activity, research has been focused on the modification of the structure of ebselen. Several structural modifications, including substituent effects and isosteric replacement, have been proposed over the years. ${ }^{11}$

Recently, Singh et al. ${ }^{12}$ have proposed the synthesis and evaluation of ebselen derivatives 7a-c, Figure 2. With exception of compound 7a, these compounds possessing an ortho-coordinating amide group are more active as a GPx mimic than the parent ebselen. ${ }^{12}$ The enhanced activity of these derivatives is attributed to the intramolecular nonbonding interactions between the oxygen of the amide moiety and selenium. These findings are supported by the elucidation of the crystal X-ray structure of the tested 
compounds. Messali and collaborators reported in 2007 the preparation of six-membered ring homologues of ebselen 8a-c. The authors showed that compound $\mathbf{8 b}$ increased the rate of reduction of $\mathrm{H}_{2} \mathrm{O}_{2}$ compared to ebselen as a control drug. ${ }^{13}$

Encouraged by the successful results found for ebselen as a powerful GPx mimic, an intensive research effort has been made toward the design of new classes of organoselenium compounds with catalytic activity as GPx like drugs. In 1989 Spector et al. ${ }^{14}$ described the enhanced activity of diphenyl diselenide 9, Figure 3, compared to ebselen. ${ }^{14}$ The same group also showed that the substituted diselenide $\mathbf{1 0}$ with a chelating group is 5-fold more active than $\mathrm{PhSe})_{2}$ in this assay.

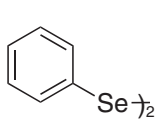

9

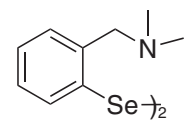

10

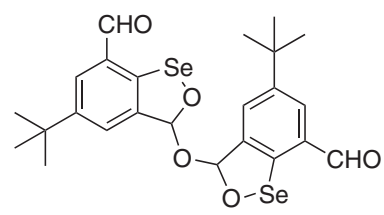

12

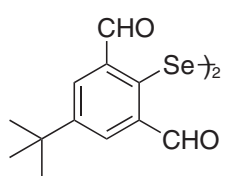

11

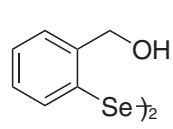

13

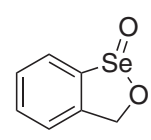

14
Figure 3. Diselenides 9, 10, 11 and $\mathbf{1 3}$ with GPx like activity.

A further approach was described by Singh and coauthors, ${ }^{15}$ diselenide 11 and the selenenate 12, which was synthesized from 11 via halogenation in water, had initial rates approximately 7 and 6-fold enhanced, respectively, compared with the catalyst $\mathbf{1 0} .^{15}$ The same author also studied the behavior of diselenide $\mathbf{1 3}$ with intramolecular Se...O nonbonding interactions and cyclic seleninate ester $\mathbf{1 4}$, which is conveniently produced by oxidation of $\mathbf{1 3}$ with $\mathrm{H}_{2} \mathrm{O}_{2} \cdot{ }^{16}$ Both substances exhibited better GPx like activity than ebselen.

Mugesh and co-authors ${ }^{17}$ showed that the ability of diaryl diselenides incorporating tertiary amino groups to mimic GPx can be dramatically changed by simple replacement of a hydrogen atom with a methoxy group in compounds 15a-c and 16a-c, Figure $4 .{ }^{17}$ The study suggested that methoxy substituents ortho to selenium in $N, N$-dialkylbenzylamine-based compounds make the basicity of the amino groups better for the catalysis. Moreover, the presence of OMe groups prevents possible Se $\cdots \mathrm{N}$ interactions in the selenols, increasing their zwitterionic characters. The methoxy substituents also protect the selenium in the selenenic acid intermediates from overoxidation to seleninic acids or irreversible inactivation to selenonic acid derivatives. Later, the same group also compared the previously mentioned diselenides possessing a tertiary amino group 15a-c with diselenides assembled with secondary amino substituents $17 \mathbf{a}-\mathbf{c} .^{18}$ Their findings revealed that replacement of the tert-amino groups in benzylamine-based diselenides by sec-amino moieties drastically enhances the catalytic activity of the studied compounds. This distinct behavior was attributed to differences in the stability and reactivity of some of the key intermediates which account for the GPx like activity. It was observed that the sec-amino groups were better than the tert-amino moieties for generating the catalytically active selenols. Furthermore, the seleninic acids $\left(\mathrm{RSeO}_{2} \mathrm{H}\right)$ derived from the sec-amine based compounds were more stable toward further reactions with peroxides than their tert-amine based analogues.
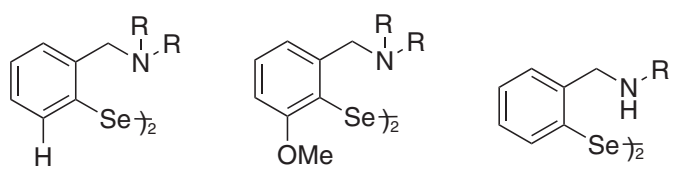

15a: $R=M e$

15b: $R=E t$

15c: $R=P r$

17a: $R=M e$

17b: $R=E t$
17c: $R=P r$<smiles>COC(=O)[C@H](Cc1ccccc1)NC(=O)[Te][Te]</smiles>

18a: $n=1$
18b: $n=2$
18c: $n=3$

Figure 4. Diselenides 15-18 with pronounced GPx like activity.

In 2009, Braga et al. ${ }^{19}$ described the synthesis of compounds 18a-c, a new class of chiral diselenides derived from amino acids. ${ }^{19}$ It was observed that the influence of the chain length between the diselenide moiety and amino acid residue played a crucial role in modulating the GPx like activity of the tested diselenides. Compounds $\mathbf{1 8 c}$ and $\mathbf{1 8 b}$ derived from L-phenylalanine with a longer chain length, showed better results than $\mathrm{PhSe})_{2}$, while compound 18a, with a shorter chain length, was the least effective catalyst screened.

Perhaps in the past decade the most studied organoselenium compounds with ability to mimic the enzyme glutathione peroxidase were the selenides and their derivatives. The first example was designed by Engman and collaborators in $1994 .{ }^{20}$ They tested compound 19, Figure 5, as a GPx mimic. Actually, 19 is a pro-catalyst, the true active compound is $\mathrm{PhSe})_{2}$, formed by cleavage of the aliphatic carbon-selenium bond of $\mathbf{1 9}$. 


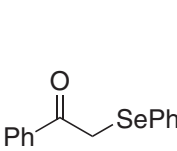

19

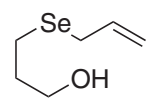

22<smiles>Oc1ccc2c(c1)CC[Se]2</smiles>

20

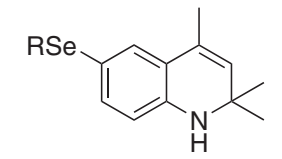

21a: $R=E t$

21b: $R=P h$

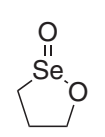

23
24

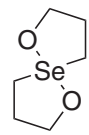

25

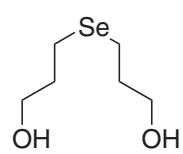

Figure 5. GPx like mimics selenides 19-25.

Latter, the same group described the synthesis and evaluation of a series of organochalcogenides 20. ${ }^{21}$ Although selenide 20 showed some GPx like activity, it was a poorer catalyst as compared to the telluride analogue. More recently, they disclosed their findings in the preparation of a new series of selenides $\mathbf{2 1 a}-\mathbf{b}$, derived from quinoline. ${ }^{22}$ While selenide 21b was a catalyst comparable to $\mathrm{PhSe}{ }_{2}$, 21a possessing a ethylseleno moiety was approximately 3-fold more active than $\mathrm{PhSe})_{2}$.

Over the past few years, Back and collaborators have been working extensively on the preparation and screening of a number of organoselenium compounds with enhanced ability to mimic the behavior of the enzyme glutathione peroxidase. In 2002, they reported the preparation of allyl selenide 22, Figure 5. They observed that $\mathbf{2 2}$ actually was a pro-catalyst that generates the unusual cyclic seleninate ester $\mathbf{2 3}$ through a series of oxidation reactions and sigmatropic rearrangement steps upon the GPx like reaction conditions. ${ }^{23}$ The novel heterocycle $\mathbf{2 3}$ was significantly more effective as a GPx mimic than ebselen 6. Furthermore, the same group also described the synthesis of selenide $\mathbf{2 4}$. Similarly to selenide $\mathbf{2 2}$ the experiments revealed that selenide $\mathbf{2 4}$ was an exceptional catalyst, much better than the widely studied compound ebselen 6 under the same conditions. Notable, they found that selenide $\mathbf{2 4}$ was a proactive compound, delivering the unusual spirodioxaselenanonane $\mathbf{2 5}$ as the real catalyst during the GPx like cycle. ${ }^{24}$

Due to the toxicity associated to alkylselenides, the authors reported latter an extension of the earlier investigation with aromatic congeners of $\mathbf{2 3}$ and $\mathbf{2 5}$, namely 26, 27, 28 and 29, Figure $6 .{ }^{25}$ However, the new compounds proved to be inferior catalysts compared to the parent cyclic seleninate ester $\mathbf{2 3}$ and spirodioxyselenurane $\mathbf{2 5}$. In 2008, after a judicious screening of substituent effects in aromatic seleninate esters $\mathbf{2 8 a}-\mathbf{g}$ and spirodioxyselenurane 29a-g Back et al. ${ }^{26}$ found that the ability of both classes of compounds to mimic the enzyme GPx could be conveniently enhanced by the addition of electron donating groups in the framework of $\mathbf{2 8}$ and $\mathbf{2 9} .{ }^{26}$ Especially noteworthy was the fact that the methoxy substituted spirodioxyselenurane $\mathbf{2 8 g}$ displayed a catalytic activity superior to that of all of the other aromatic compounds and approaches that of the aliphatic analogue 23. Another approach was described in the synthesis and characterization of spirodiazaselenurane 30, possessing a covalent $\mathrm{N}-\mathrm{Se}$ bond, as well as a noncovalent interaction between the selenium atom and the carbonyl oxygen atom of the other amide moiety as determined by spectroscopic and X-ray crystallographic methods. ${ }^{27}$ The synthesized compound functioned as an effective GPx mimetic, with catalytic activity superior to that of ebselen $\mathbf{6}$.

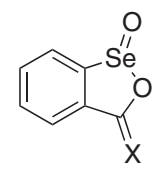

26a: $X=H, H$ 26a: $X=H, H$
26b: $X=O$<smiles>[R]c1ccc2c(c1)CO[Se-]21OCc2cc(C)ccc21</smiles>

29a: $R=H$

29b: $R=F$

29c: $\mathrm{R}=\mathrm{Cl}$

29d: $\mathrm{R}=\mathrm{Br}$

29e: $R=M e$

29f: $\mathrm{R}=\mathrm{Ph}$

29g: $\mathrm{R}=\mathrm{OMe}$

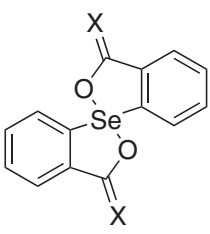

27a: $X=H, H$ 27b: $X=O$

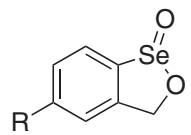

28a: $R=H$ 28b: $R=F$ 28c: $\mathrm{R}=\mathrm{Cl}$ 28d: $R=B r$ 28e: $R=M e$ 28f: $R=P h$

28g: $\mathrm{R}=\mathrm{OMe}$

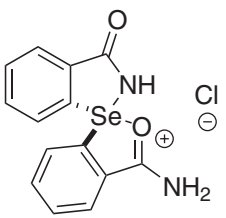

30
Figure 6. Selenides 26-30 with GPx like activity.

Mugesh et al. ${ }^{28}$ proposed the synthesis of aryl-substituted L-selenocysteine derivative $\mathbf{3 1}$ containing a basic amino group, Figure $7{ }^{28}$ Their results supported that amino groups in close proximity to selenium could increase the stability of 31 derivatives by intramolecular $\mathrm{Se} \cdot \mathrm{N}$ interactions. These interactions appear to modulate the reactivity of selenium toward the GPx reaction conditions. They also suggested that the internally chelated L-Selenocysteine derivative $\mathbf{3 1}$ could be used as pro-catalyst for generating catalytically active selenols. The fast and mild oxidative elimination of $\mathbf{3 1}$ derivatives to produce dehydroalanines, therefore, may give easy access to biologically active selenium compounds. Kuhn and coauthors ${ }^{29}$ have demonstrated that seleninic acid anhydride 32, derived from salicyloylglycine exhibits a higher glutathione peroxidase like activity, fourfold higher than ebselen. ${ }^{29}$ Very recently, Iwaoka et al. ${ }^{30}$ investigated the antioxidative catalytic activities of 
trans-3,4-dihydroxyselenolane 33, a water soluble cyclic selenide ${ }^{30}$ Although the observed GPx like catalytic activities were not so remarkable as those of previous GPx model compounds, the water solubility of $\mathbf{3 3}$ certainly would be useful not only for the molecular design of new GPx mimics with enhanced antioxidative catalytic activity but also for biological applications as an efficient catalyst for the formation of sulfur-sulfur linkages in proteins.

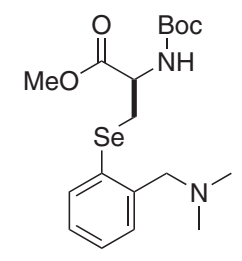

31<smiles>O=C(O)CNC(=O)c1cc(O[Se](=O)(=O)c2ccc(O)c(C(=O)NCC(=O)O)c2)ccc1O</smiles>

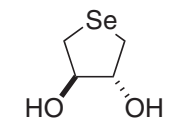

33

32

Figure 7. Selenium compounds $\mathbf{3 1 - 3 3}$ that exhibit GPx like behavior.

\subsection{Organotellurium compounds}

Based on the recognized success that synthetic organoselenium compounds exhibited acting as GPx like substances, and the redox properties of tellurium, several research groups have also investigated the ability of organotellurium compounds to mimic the enzyme glutathione peroxidase. A noteworthy characteristic of organotellurium compounds is their much improved antioxidant activity when compared with their selenium and sulfur analogues. The first example of organotellurium compound 34, Figure 8, described as a possible GPx mimic, was reported by Detty in $1992 .{ }^{31}$ After that, a series of ditellurides and tellurides have been reported in the literature. Engman et al. ${ }^{21}$ have shown that the antioxidant capacity of telluride $\mathbf{3 5}$ is drastically increased when compared with their selenium congeners $20 .{ }^{21}$ Later, in 2004, the same group described the synthesis and GPx like behavior of water soluble cyclodextrin derivatives containing tellurium, 36a-e. ${ }^{32}$ Among organotellurides 36a-e, the cyclodextrin 36e carrying a butyltelluro group was the best catalyst. They also found that the catalytic efficiency of aryl derivatives decreased with decreasing electron density at tellurium $(\mathbf{3 6 d}>\mathbf{3 6} \mathbf{c} \cong \mathbf{3 6} \mathbf{b}>\mathbf{3 6} \mathbf{a})$. Furthermore, the selenium analogue, showed poor catalytic efficiency.

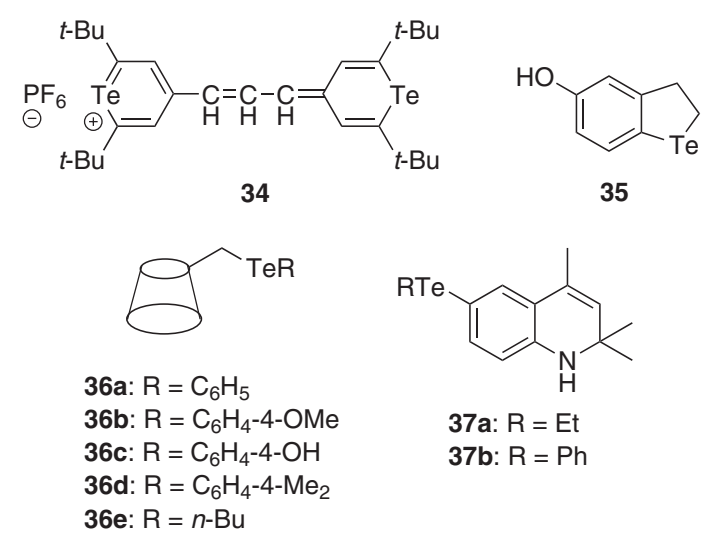

Figure 8. Tellurides 34-37 with GPx like activity.

Following their initial findings, Engman and co-authors ${ }^{22}$ described the preparation and screening of tellurides $\mathbf{3 7 a}-\mathbf{b}$. Similarly to previous reports, they found that telluride possessing an alkyl moiety 37a was a superior GPx mimic compared to the telluride with an aryl substituent 37b. However, both tellurides 37a-b, had an enhanced glutathione peroxidase activity when compared to their selenium analogues. ${ }^{22}$

The same group recently described the preparation and the structure-reactivity relationship as GPx mimics of two series of tellurides, 38a-b and 39a-d, Figure $9 .{ }^{33}$ Their results indicated that both the proximity of chelating oxygen near to the active site and electronic effects are crucial for the catalytic performance of the tested compounds. Telluride 39a, carrying a hydroxyl group ortho to tellurium was a superior GPx mimic than 38a. The increase of the number of electron donating groups attached in the pyridyl ring also had a positive effect in the efficiency of the compounds. The most active was compound 39d, carrying a methoxy group in para position to tellurium, the GPx like activity of this telluride is 25 -fold enhanced when compared with $\mathrm{PhSe})_{2}$.

Independently to Engman's results, Detty and coauthors have demonstrated that the GPx like behavior of tellurides is strongly modulated by alkyl groups attached in the tellurium atom. ${ }^{34}$ Electron rich telluride 41a displayed greater rate acceleration than the diaryl tellurides $\mathbf{4 0}$ and $\mathbf{4 1 b}$ as determined by the initial rates. While compounds $\mathbf{4 1 b}$ and $\mathbf{4 0}$ are comparable catalysts, with an increased activity of 13-fold and 12-fold higher then $\mathrm{PhSe})_{2}$, respectively, telluride 41a is approximately 5 -fold more effective than them, and 55-fold more active than $\mathrm{PhSe})_{2}$.

A common strategy to evaluate the GPx like activity of organotellurides is to compare their efficiency to their selenium congeners. According to this, Singh et al. ${ }^{12}$ prepared a series of novel ebselen derivatives, and also a 


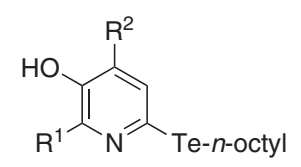

38a: $R^{1}=H, R^{2}=H$

38b: $R^{1}=M e, R^{2}=M e$

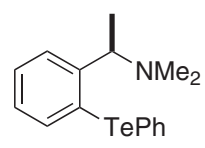

40

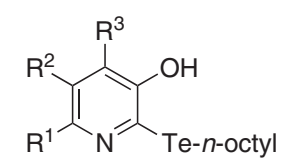

39a: $R^{1}=H, R^{2}=H, R^{3}=H$

39b: $R^{1}=M e, R^{2}=H, R^{3}=H$

39c: $R^{1}=M e, R^{2}=H, R^{3}=M e$

39d: $R^{1}=M e, R^{2}=O M e, R^{3}=M e$

$\mathrm{R}-\mathrm{Te}-\mathrm{R}$

41a: $\mathrm{R}=n-\mathrm{C}_{6} \mathrm{H}_{13}$

41b: $\mathrm{R}=\mathrm{C}_{6} \mathrm{H}_{4}-4-\mathrm{OMe}$
Figure 9. Tellurium compounds 38-41 with GPx like activity.

tellurium analogue $\mathbf{4 2}$, Figure $10 .{ }^{12}$ Telluride $\mathbf{4 2}$ showed a 1.5-fold higher activity than its selenium analogues 7a-c and approximately 5 -fold better activity then ebselen. In the same way, Back and collaborators, ${ }^{25}$ have prepared several novel organo-selenium and tellurium compounds and evaluated them as mimetics of the selenoenzyme glutathione peroxidase. ${ }^{25}$ The cyclic tellurinate ester $\mathbf{4 3}$ and spirodioxytellurane $\mathbf{4 4}$ proved to be a superior catalysts to their selenium analogues $\mathbf{2 3}$ and $\mathbf{2 5}$, respectively, resulting in the fastest reaction rates by far of all of the compounds that they have investigated to date.<smiles></smiles>

42

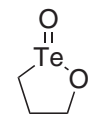

43

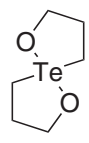

44
Figure 10. Tellurides 42-44 that exhibit GPx like behavior.

Recently our group described the synthesis and GPx like screening of novel telluroaminoacid derivatives 45a-g, Figure $11 .^{35}$ For a better understanding of the structure-activity relationship of the compounds and to find a more efficient catalyst, we promoted the variation of amino acid residues and the chain length between the chalcogen atom and the amino acid moiety. Our prime concern in the evaluation of compounds 45a-g as GPx mimics was the influence of the chain length between the tellurium atom and amino acid moiety. We found that compounds $\mathbf{4 5 a}$ and $\mathbf{4 5 b}$ derived from L-valine showed the same activity. Taking advantage of the modular characteristic of our synthetic route, we explored the influence of the amino acid residue in the modulation of the GPx mimetic activity of these telluroaminoacids. Compounds 45c and 45d derived from L-phenylalanine were tested under the same conditions. Compound $\mathbf{4 5 c}$, with a shorter chain length, showed the same catalytic activity as that of compounds 45a and $\mathbf{4 5 b}$. However, $\mathbf{4 5 d}$ was less effective in the reduction of hydrogen peroxide. On the basis of these initial observations, we used telluroaminoacids with $\mathrm{n}=2$ as standard catalysts, and promoted the variation of amino acid moiety to enhance their ability to mimic the glutathione peroxidase enzyme. Among all compounds tested, we found that telluride $\mathbf{4 5 g}$ derived from L-aspartic acid was the best catalyst.

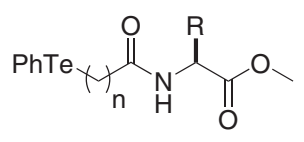

Amino Acid

$\begin{array}{ll}\text { 45a L-valine } & 2 \\ \text { 45b L-valine } & 3 \\ \text { 45c L-phenylalanine } & 2 \\ \text { 45d L-phenylalanine } & 3 \\ \text { 45e L-alanine } & 2 \\ \text { 45f L-leucine } & 2 \\ \text { 45g L-aspartic acid } & 2\end{array}$<smiles>COC(=O)CC(NC(=O)CC[Ga])C(=O)OC</smiles>

45i $\mathrm{R}=p$-tolyl

45j $R=0$-tolyl

45k $\mathrm{R}=4$-methoxyphenyl

45I $\mathrm{R}=4$-chlorophenyl

$45 \mathrm{mR}=2$-chlorophenyl

45n $\mathrm{R}=2$-naphthalene

45o $R=1$-naphthalene
Figure 11. Telluro amino acids derivatives 45 a-o with GPx like activity.

Encouraged by these results, we next explored the effects of substituents in the aryl group attached to tellurium. A new series of telluroaminoacids were prepared with electron donating 45i-k, electron withdrawing 451 and $\mathbf{4 5 m}$, as well as with sterically hindered substituents 45n and 45o. We found that the GPx like behavior of these compounds was strongly influenced by steric effects. The activity of para substituted compounds was, on average, 2 -fold higher than that of the ortho analogues. Although the electronic environment at tellurium atom did not produce a pronounced difference in the thiol peroxidase activity of these compounds, the best telluride screened in our assay was compound $\mathbf{4 5 k}$, with a methoxy group attached in the para position of the aromatic ring.

\subsection{Mechanisms of action of organochalcogen compounds as GPx like catalysts}

Additionally to the design of new organochalcogen compounds able to mimic the activity of the enzyme glutathione peroxidase, the pursuit of a deeper understanding of the mechanism of action of these catalysts is an area of intensive research nowadays. Naturally, once different classes of organochalcogen compounds exhibit GPx like behavior, several distinct mechanisms have been postulated to explain their action.

In this context, selenides containing Se-N bonds were one of the first class of compounds investigated. Although ebselen $\mathbf{6}$, is one of the most studied compound as GPx 
like, ${ }^{36}$ its catalytic cycle has not been clearly elucidated. A possible mechanism pathway is illustrated in Scheme 3.

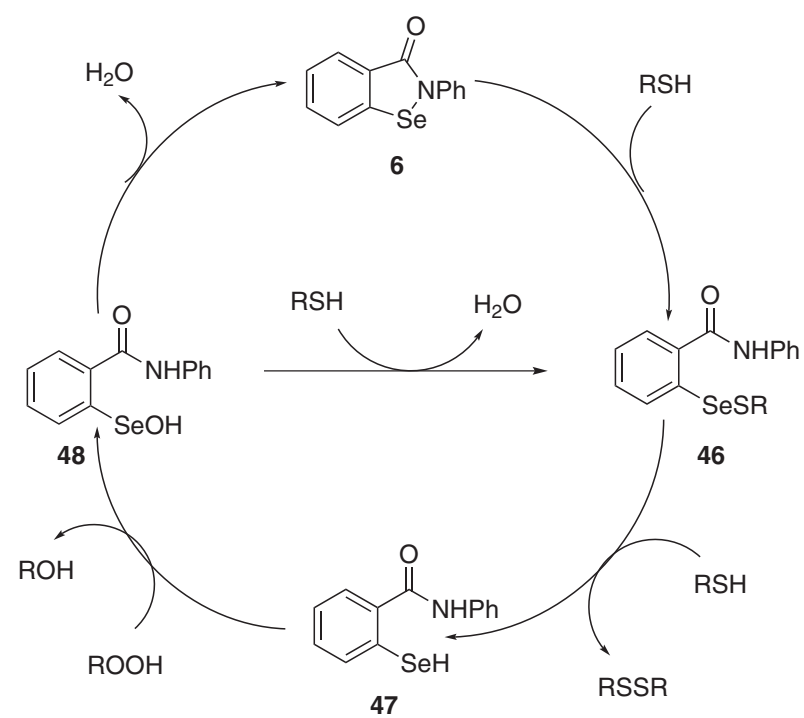

Scheme 3. Possible mechanism pathway of ebselen 6 .

Initially, ebselen $\mathbf{6}$ reacts with a thiol (RSH) to produce the intermediate selenenyl sulfide 46. Reaction of the latter with another equivalent of thiol, delivers the selenol 47, which is the responsible for the reduction of the peroxide and formation of selenenic acid $\mathbf{4 8}$. At this point two different pathways are proposed: reaction with another equivalent of thiol to regenerate the selenenyl sulfide $\mathbf{4 6}$, or the loss of one molecule of water from selenenic acid 48, to give ebselen 6 to resume the catalytic cycle. Mugesh and coauthors have shown that one of the crucial steps in the catalytic cycle of ebselen is the formation of selenol 47. They found that the presence of strong $\mathrm{S} \cdots \mathrm{N}$ or $\mathrm{S} \cdots \mathrm{O}$ interactions in the selenenyl sulfide $\mathbf{4 6}$ can modulate the attack of an incoming nucleophile (thiol) at the sulfur atom of the Se-S bridge and enhance the GPx activity by reducing the barrier to the formation of the active specie selenol. . $^{37}$

Another important class of organoselenium compounds with enhanced GPx like activity is the diselenides. In 1994, Tomoda et al..$^{38}$ proposed a catalytic cycle to explain their pronounced ability to reduce peroxides at the expense of thiols..$^{38}$ They postulated that the higher activity of diselenides as GPx mimics compared to ebselen is due to the formation of two active species in the catalytic cycle, the selenol $\mathbf{5 0}$ and the selenenyl sulfide $\mathbf{5 1}$ formed in the reaction of the diselenide 49 and a thiol, Scheme 4.

The mechanism of action of diselenides is depicted in Scheme 5. The active specie selenol $\mathbf{5 2}$ reacts with one equivalent of $\mathrm{H}_{2} \mathrm{O}_{2}$ to produce water and selenenic acid 53. Reaction of selenenic acid with one equivalent of thiol

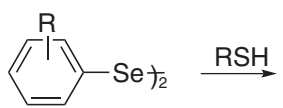

49

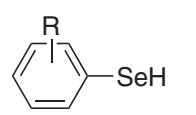

50

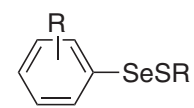

51
Scheme 4. Reaction of the diselenide 49 and a thiol.

produces water and selenenyl sulfide $\mathbf{5 4}$. Finally, $\mathbf{5 4}$ reacts with another equivalent of thiol to form disulfide and $\mathbf{5 2}$ to restart the catalytic cycle.

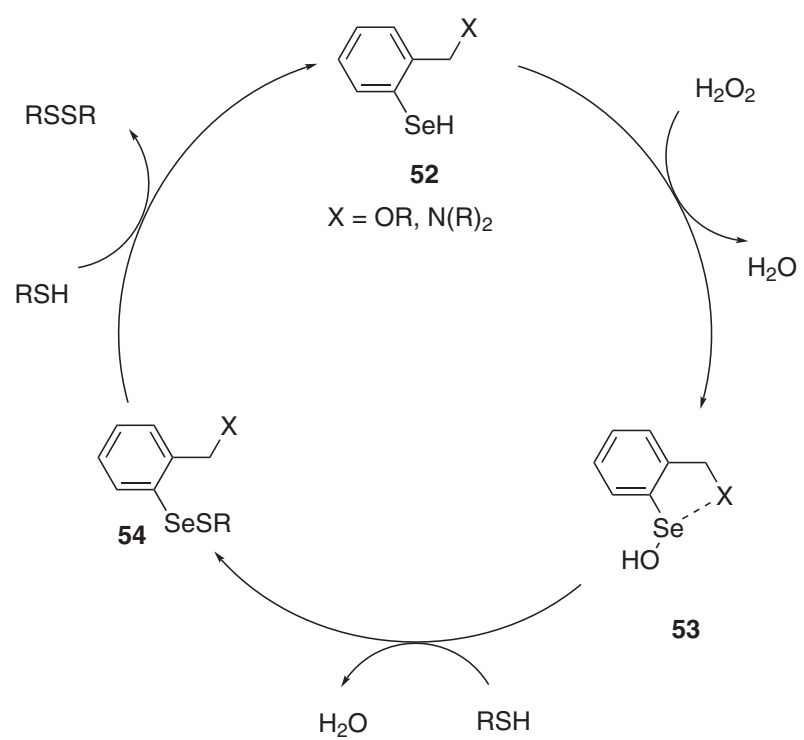

Scheme 5. Catalytic cycle of diselenides as GPx mimics.

The enhanced GPx like activity of diselenides $\mathbf{5 2}$ carrying coordinating heteroatoms such as oxygen or nitrogen is ascribed to the stabilization of selenium by nonbonding interactions like Se $\cdots \mathrm{N}$ or Se $\cdots \mathrm{O}$. These interactions play an important role modulating the activity of diselenides by preventing further oxidation by $\mathrm{H}_{2} \mathrm{O}_{2}$ of selenium in the selenenic acid $\mathbf{5 3}$ to seleninic acid which is less reactive than the specie $\mathbf{5 3}$.

Selenides and tellurides have a similar mechanism of action, which is distinct to that of ebselen derivatives and diselenides, Scheme 6. Selenides and tellurides $\mathbf{5 5}$ are readily oxidized by peroxides to the corresponding selenoxides and telluroxides $\mathbf{5 6}$. These species are then reduced by thiol to regenerate the parent selenide or telluride through the specie 57. ${ }^{39}$ This facile redox cycle allows their use as peroxide decomposers. Detty and coauthors $^{34}$ have demonstrated that the rate-limiting step in thiol peroxidase like activity of tellurides is the oxidation of tellurides to the respective telluroxide rather than the reduction process of the intermediate $\mathbf{5 7 . 3 4}$ Similarly, Iwaoka and Tomoda ${ }^{38}$ found identical behavior for selenides, following the progress of the reaction by a ${ }^{77} \mathrm{Se}$ NMR study, they ascribed that the rate-determining 
step in the catalytic cycle is the oxidation process from selenide $\mathbf{5 5}$ to the selenoxide $\mathbf{5 6}$.

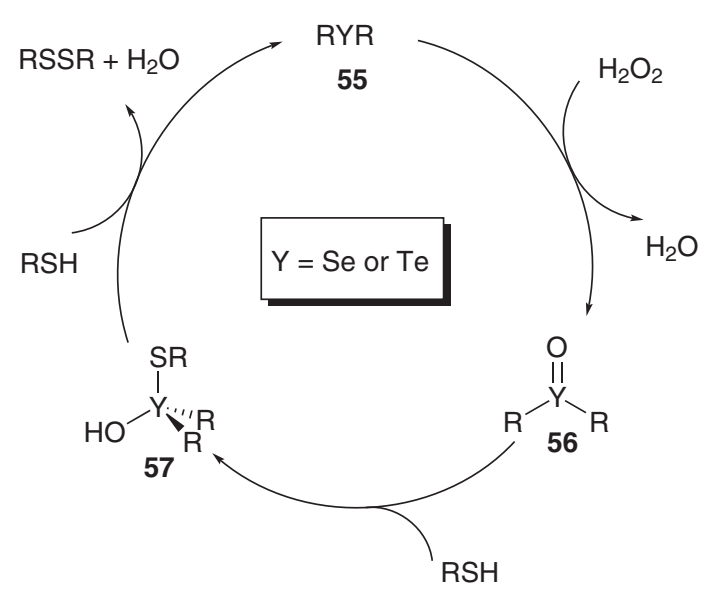

Scheme 6. Catalytic cycle of selenides or tellurides as GPx mimics.

\section{Conclusions}

In the past decade the development of new organochalcogen compounds designed to mimic the activity of the selenoenzyme glutathione peroxidase has been a subject of intensive research. Diverse classes of organoselenides and tellurides were efficiently prepared and showed pronounced GPx like activity. Recent progress has also been made in the elucidation of their mechanism of action. Nonetheless, further improvements in the field are still an exciting challenge. A deeper understanding of the detailed mechanisms of action, the toxicity of these compounds in vivo trials and also the design of water soluble catalysts, are perhaps, the most promising frontiers in this subject.

\section{Acknowledgments}

We gratefully acknowledge CNPq (INCT-Catalise) and FAPESC for financial support. E. E. A. thanks CNPq for a $\mathrm{PhD}$ fellowship.

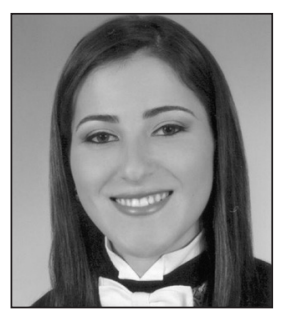

Vanessa Nascimento was born in Marau (RS State, Brazil). In 2009 she obtained her BSc degree in Chemistry from the Universidade Federal de Santa Maria. Then, she moved to the Universidade Federal de Santa Catarina, where she is currently developing her MSc activities under the supervision of Prof. Antonio L. Braga. Her research focus is the synthesis of new organoselenium compounds for catalytic application as enzyme mimetics, with emphasis on the kinetic profile of the reaction.

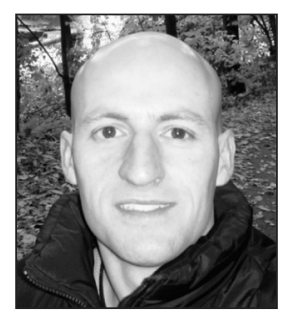

Eduardo E. Alberto was born in Santa Cruz do Sul, Brazil. He received his MSc degree from the Universidade Federal de Santa Maria in 2007. Currently his is pursuing his PhD degree under the supervision of Prof. Antonio L. Braga. In 2009 he was awarded with a fellowship to join Prof. Michael R. Detty's group over a period of six months, in the State University of New York in Buffalo. His research interests include the development of novel organoselenium compounds for catalytic application in oxidation reactions.

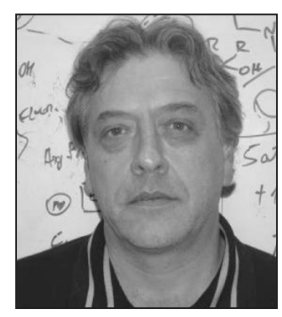

Antonio Luiz Braga was born in Herculândia (SP State) and obtained his BSc in 1982 from the Universidade Federal de São Carlos (SP State). He received his $M S c$ and $P h D$ degrees from the Universidade de São Paulo in 1984 and 1989, working under the supervision of Prof. J. V. Comasseto in the field of Organic Selenium Chemistry. In 1985 he obtained a position at the Universidade Federal de Santa Maria (RS State, South Brazil) as an Assistant Professor. From 1990 to 2009 he occupied a position at the same University as an Associate Professor. In 2009, Prof. Braga moved to Florianópolis where he became a faculty member of the Universidade Federal de Santa Catarina (SC State), as a Professor of Organic Chemistry, position that he still holds. He is also a 1A-level researcher of the National Council for Technological and Scientific Development (CNPq). His research interests mainly reside in the catalytic application of chiral organochalcogen compounds in asymmetric synthesis as well as in the preparation of organoselenium and organotellurium compounds with relevant biological activities.

\section{References}

1. Klayman, D. L.; Günter, H. H.; Organoselenium Compounds: Their Chemistry and Biology, Wiley: New York, 1973; Rotruck, J. T.; Pope, A. L.; Ganther, H. E.; Swanson, A. B.; Hafeman, D. G.; Hoekstra, W. G.; Science 1973, 179, 588; Flohé, L.; Günzler, E. A.; Schock, H. H.; FEBS Lett. 1973, 32, 132; Shamberger R. J.; Biochemistry of Selenium, Plenum Press: New York, 1983; Flohé, L.; Andreesen, J. R.; Brigelius- Flohé, R.; Maiorino, M.; Ursini, F.; IUBMB Life 2000, 49, 411.

2. Braga, A. L.; Lüdtke, D. S.; Paixão, M. W.; Alberto, E. E.; Stefani, H. A.; Juliano, L.; Eur. J. Org. Chem. 2005, 4260; Mukherjee, C.; Tiwari, P.; Misra, A. K.; Tetrahedron Lett. 2006, 
47, 441; Tiwari, P.; Misra, A. K.; Tetrahedron Lett. 2006, 47, 2345; Caputo, R.; Capone, S.; Greca, M. D.; Longobardo, L.; Pinto, G.; Tetrahedron Lett. 2007, 48, 1425; Abdo, M.; Knapp, S.; J. Am. Chem. Soc. 2008, 130, 9234; Wessjohann, L. A.; Schneider, A.; Chem. Biodiversity 2008, 5, 375 and references cited therein; Braga, A. L.; Filho, W. A. S.; Schwab, R. S.; Rodrigues, O. E. D.; Dornelles, L.; Braga, H. C.; Lüdtke, D. S.; Tetrahedron Lett. 2009, 50, 3005.

3. Sies, H.; Oxidative Stress: Introductory Remarks, Academic Press: London, 1985; Sies, H.; Angew. Chem., Int. Ed. 1986, 25, 1058.

4. Flohe, L.; Pryor, W. A.; Free Radicals in Biology, Academic Press: New York, 1982.

5. Stadtman, T. C.; J. Biol. Chem. 1991, 266, 16257; Ursini, F.; Paoletti, R.; Oxidative Processes and Antioxidants, Raven Press: New York, 1994.

6. Flohé, L.; Glutathione: Chemical, Biochemical, Medical Aspects, John Wiley \& Sons: New York, 1989; Böck, A.; Encyclopedia of Inorganic Chemistry: Selenium Proteins Containing Selenocysteine, John Wiley \& Sons: Chichester, 1994.

7. Wendel, A.; Pilz, W.; Ladenstein, R.; Sawatzki, G.; Weser, U.; Biochim. Biophys. Acta 1975, 377, 211; Epp, O.; Ladenstein, R.; Wendel A.; Eur. J. Biochem. 1983, 133, 51.

8. Sharpless, K. B.; Gordon, K. M.; Lauer, R. F.; Patrick, D. W.; Singer, S. P.; Young, M. W.; Chem. Scr. 1975, 8A, 9; Reich, H. J.; Acc. Chem. Res. 1979, 12, 22.; Detty, M. R.; Merkel, P. B.; Powers, S. K.; J. Am. Chem. Soc. 1988, 110, 5920; Detty, M. R.; Organometallics 1991, 10, 702.

9. For comprehensive reviews see: Mugesh, G.; Singh, H.; Chem. Soc. Rev. 2000, 29, 347; Mugesh, G.; du Mont, W. W.; Sies, H.; Chem. Rev. 2001, 101, 2125; Mugesh, G.; du Mont, W. W.; Chem. Eur. J. 2001, 7, 1365; Jacob, C.; Giles, G. I.; Giles, N. M.; Sies, H.; Angew. Chem. Int. Ed. 2003, 42, 4742; Nogueira, C. W.; Zeni, G.; Rocha, J. B. T.; Chem. Rev. 2004, 104, 6255; Sarma, B. K.; Mugesh, G.; Org. Biomol. Chem. 2008, $6,965$.

10. Ruwet, A.; Renson, M.; Bull. Soc. Chim. Belg. 1969, 78, 571; Weber, R.; Renson, M.; Bull. Soc. Chim. Fr. 1976, 1124; Müller, A.; Cadenas, E.; Graf, P.; Sies, H.; Biochem. Pharmacol. 1984, 33, 3235; Wendel, A.; Fausel, M.; Safayhi, H.; Tiegs, G.; Otter, R.; Biochem. Pharmacol. 1984, 33, 3241; Lambert, C.; Hilbert, M.; Christiaens, L.; Dereu, N.; Synth Commun. 1991, 21, 85; Sies, H.; Free Radical Biol. Med. 1993, 14, 313; Fong, M. C.; Schiesser, C. H.; J. Org. Chem. 1997, 62, 3103; Sies, H.; Masumoto, H.; Adv. Pharmacol. 1997, 38, 22229; Zade, S. S.; Panda, S.; Singh, H. B.; Wolmershäuser, G.; Tetrahedron Lett. 2005, 46, 665.

11. Parnham, M. J.; Biedermann, J.; Bittner, Ch.; Dereu, N.; Leyck, S.; Wetzig, H.; Agents Actions 1989, 27, 306; Renson, M.; Dereu, N.; J. Pharm. Belg. 1990, 45, 322.
12. Zade, S. S.; Panda, S.; Tripathi, S. K.; Singh, H. B.; Wolmershäuser, G.; Eur. J. Org. Chem. 2004, 3857.

13. Messali, M.; Christiaens, L. E.; Alshahateet, S. F.; Kooli, F.; Tetrahedron Lett. 2007, 48, 7448.

14. Wilson, S. R.; Zucker, P. A.; Huang, R. R. C.; Spector, A.; J. Am. Chem. Soc. 1989, 111, 5936.

15. Zade, S. S.; Singh, H. B.; Butcher, R. J.; Angew. Chem. Int. Ed. 2004, 43, 4513.

16. Tripathi, S. K.; Patel, U.; Roy, D.; Sunoj, R. B.; Singh, H. B.; Wolmershaüser, G.; 17. Butcher, R. J.; J. Org. Chem. 2005, 70, 9237 .

17. Bhabak, K. P.; Mugesh, G.; Chem. Eur. J. 2008, 14, 8640.

18. Bhabak, K. P.; Mugesh, G.; Chem. Eur. J. 2009, 15, 9846.

19. Alberto, E. E.; Soares, L. C.; Sudati, J. H.; Borges, A. C. A.; Rocha, J. B. T.; Braga, A. L.; Eur. J. Org. Chem. 2009, 4211.

20. Engman, L.; Andersson, C.; Morgenstern, R.; Cotgreave, I. A.; Andersson, C. M.; Hauberg, A.; Tetrahedron 1994, 50, 2929.

21. Malmstrolm, J.; Jonsson, M.; Cotgreave, I. A.; Hammarstrolm, L.; Sjoldin, M.; Engman, L.; J. Am. Chem. Soc. 2001, 123, 3434; Kumar, S.; Johansson, H.; Engman, L.; Valgimigli, L.; Amorati, R.; Fumo, M. G.; Pedulli, G. F.; J. Org. Chem. 2007, $72,2583$.

22. Kumar, S.; Engman, L.; Valgimigli, L.; Amorati, R.; Fumo, M. G.; Pedulli, G. F.; J. Org. Chem. 2007, 72, 6046.

23. Back T. G.; Moussa, G.; J. Am. Chem. Soc. 2002, 124, 12104; Back, T. G.; Moussa, Z. J. Am. Chem. Soc. 2003, 125, 13455.

24. Back, T. G.; Moussa, Z.; Parvez, M.; Angew. Chem. Int. Ed. 2004, 43, 1268.

25. Back, T. G.; Kuzma, D.; Parvez, M.; J. Org. Chem. 2005, 70, 9230.

26. Press, D. J.; Mercier, E. A.; Kuzma, D.; Back, T. G.; J. Org. Chem. 2008, 73, 4252.

27. Kuzma, D.; Parvez, M.; Back, T. G.; Org. Biomol. Chem. 2007, 5, 3213.

28. Phadnis, P. P.; Mugesh, G.; Org. Biomol. Chem. 2005, 3, 2476.

29. Yu, S. C.; Borchert, A.; Kuhn, H.; Ivanov, I.; Chem. Eur. J. 2008, 14, 7066.

30. Kumakura, F.; Mishra, B.; Priyadarsini, K. I.; Iwaoka, M.; Eur. J. Org. Chem. 2010, 440.

31. Detty, M. R.; Gibson, S. L.; Organometallics 1992, 11, 2147.

32. McNaughton, M.; Engman, L.; Birmingham, A.; Powis, G.; Cotgreave, I. A.; J. Med. Chem. 2004, 47, 233.

33. Kumar, S.; Johansson, H.; Kanda, T.; Engman, L.; Müller, T.; Jonsson, M.; Pedulli, G. F.; Petrucci, S.; Valgimigli, L.; Org. Lett. 2008, 10, 4895.; Kumar, S.; Johansson, H.; Kanda, T.; Engman, L.; Müller, T.; Bergenudd, H.; Jonsson, M.; Pedulli, G. F.; Amorati, R.; Valgimigli, L.; J. Org. Chem. 2010, 75, 716.

34. You, Y.; Ahsan, K.; Detty, M. R.; J. Am. Chem. Soc. 2003, 125, 4918.

35. Braga, A. L.; Alberto, E. E.; Soares, L. C.; Rocha, J. B. T.; Sudati, J. H.; Ross, D. H.; Org. Biomol. Chem. 2009, 7, 43. 
36. Selected examples: Fisher, H.; Dereu, N.; Bull. Soc. Chim. Belg. 1987, 96, 757; Kice, J. L.; Purkiss, D. W.; J. Org. Chem. 1987, 52, 3448; Glass, R. S.; Farooqui, F.; Sabahi, M.; Ehler, K. W.; J. Org. Chem. 1989, 54, 1092; Engman, L.; Stern, D.; Cotgreave, I. A.; Andersson, C. M.; J. Am. Chem. Soc. 1992, 114, 9737.

37. Sarma, B. K.; Mugesh, G.; J. Am. Chem. Soc. 2005, 127, 11477.
38. Iwaoka, M.; Tomoda, S.; J. Am. Chem. Soc. 1994, 116, 2557.

39. Detty, M. R.; Friedman, A. E.; Oserof, A. R.; J. Org. Chem. 1994, 59, 8245 .

Submitted: April 15, 2010

Published online: August 24, 2010 